\title{
Removal of landfill leachate toxicity and genotoxicity by two treatment methods
}

\author{
Sandra Radić Brkanac ${ }^{1}$, Valerija Vujčić ${ }^{1}$, Petra Cvjetko ${ }^{1}$, Vid Baković ${ }^{1}$, and Višnja Oreščanin ${ }^{2}$ \\ Department of Biology, Faculty of Science, University of Zagreb ${ }^{1}$, Advanced Energy Ltd. ${ }^{2}$, Zagreb, Croatia
}

Received in July 2013

CrossChecked in July 2013

Accepted in September 2013

\begin{abstract}
Leachates from active and closed municipal solid waste landfills can be a major source of contamination to groundwater and surface waters. In the present study the toxic and genotoxic potential of leachate from an old sanitary landfill prior to and following chemical and electrochemical treatments were assessed using Lemna, Allium, and comet tests. Photosynthetic pigments, malondialdehyde (indicator of lipid peroxidation) and antioxidant enzyme activities were evaluated as additional indicators of toxicity in duckweed. Following duckweed exposure to $25 \%$ dilution of landfill leachate, growth rate and photosynthetic pigments content significantly decreased while lipid peroxidation increased despite stimulation of antioxidative defence mechanisms. Diluted leachate induced DNA strand breaks in duckweed cells as evidenced by the comet assay. Regarding the Allium test, untreated leachate caused inhibition of Allium cepa cell division and induction of mitotic and chromosomal aberrations. Although both water treatments completely reduced genotoxicity of leachate, the electrochemical method was found to be more efficient in removing toxic substances present in landfill leachate and thus more suitable for treating such leachates prior to their discharge into the environment. As landfill leachates pose a risk to human health and environment in general due to their (geno)toxicity, the present study demonstrates that the ecotoxicity/genotoxicity assays should be used in leachate risk assessment together with physicochemical analysis.
\end{abstract}

KEY WORDS: Allium test; comet assay; Lemna test; oxidative stress indicators; water treatment

The exponential growth of population, accelerated urbanisation and continuing technological development in industry has been accompanied by the rapid generation of municipal and industrial solid wastes. Today, landfilling is still the most widely utilised method for the ultimate disposal of solid waste material around the world. Its purpose is to isolate degrading waste from its environment. However, if not properly isolated, sanitary landfill can stretch to new localities and contaminate water sources including underground waters while the contamination of plant and animal habitats could have severe effects on biodiversity and population size.

The most commonly used methods for treating landfill leachate include biological methods based on aerobic or anaerobic processes, membrane technologies, physicochemical methods, and electrochemical methods (1). Genotoxic and toxic effects of landfill leachates have been proved in a number of studies using various plant and animal test systems (2-4). In the present study, the efficacy of the two newly developed treatment methods $(5,6)$ for reducing toxicity and genotoxicity caused by landfill 
leachate was investigated. The chemical treatment procedure combined chemical precipitation with $\mathrm{CaO}$ followed by coagulation with ferric chloride and final adsorption by clinoptilolite while the electrochemical treatment approach included pretreatment with ozone followed by electrooxidation/electrocoagulation and final polishing by microwave irradiation. Both treatments were tested on the leachate from the old sanitary landfill Piškornica (Koprivnica, Croatia) and have proved to be highly efficient in removing chemical parameters such as colour, turbidity, suspended solids, ammonia, COD, Fe, and Zn. However, suitability and safety of these methods must be confirmed prior to their wide range applications by toxicological characterization using various tests. Higher plants provide a very useful, simple and inexpensive tool for the first-step screening of environmental pollutants. Both plants, Allium cepa L. and Lemna minor L., used in the present study possess certain physiological properties desirable in the ideal test systems (7-9). Potential genotoxicity of landfill lechate was also evaluated by the comet assay using duckweed nuclei.

The aim of the present study was to evaluate the cytotoxic and genotoxic potential of leachate from an old sanitary landfill prior to and following chemical and electrochemical treatments on plant cells.

\section{MATERIALS AND METHODS}

\section{Sampling sites and sampling handling}

The landfill leachate was collected from the lagoon of Piškornica, old sanitary landfill, Koprivnica, Croatia. Municipal and industrial waste has been deposited at the landfill since 1982. Until 2005, waste was disposed directly onto the ground without a basic leak-proof layer or any sort of cover over the deposited waste nor was there any collection or treatment of water leakage from the site. Since 2005, sanitary steps have been made as an attempt to isolate the deposited waste from its environment (5). One hundred litres of the leachate were collected in five polyethylene containers and transported to the laboratory. In order to obtain homogeneous sample the effluent was combined into the single tank and mixed for $10 \mathrm{~min}$ on a magnetic stirrer before analysis or each purification experiment. All purification experiments were conducted at room temperature and were done in triplicate.

\section{Chemical treatment}

In order to decrease high organic load and suspended solids, calcium oxide (Lika lime factory, Ličko Lešće, Croatia) was mixed with the landfill leachate. The suspension was mixed on a magnetic stirrer for $30 \mathrm{~min}$. It was then allowed to settle, the liquid part was decanted and the rest of the sample was subjected to a further treatment by $0.570 \mathrm{mg} \mathrm{L}^{-1}$ of $\mathrm{Fe}^{3+}$ added in the form of $\mathrm{FeCl}_{3} \times 6 \mathrm{H}_{2} \mathrm{O}$ (Kemika, Zagreb, Croatia). Following another cycle of stirring, settling and decanting, a dose of $25 \mathrm{~g} \mathrm{~L}^{-1}$ of powdered clinoptilolite (taken from Donje Jesenje mine, Croatia) was added to the precipitate. Following six hours of stirring and settling, the liquid part was decanted and analysed (5).

\section{Electrochemical treatment}

Laboratory scale electrocoagulation experiments were done in quadratic polyethylene vessels. For each experiment $10 \mathrm{~L}$ of water was taken and subjected to ozonation followed by simultaneous ozonation and electrochemical treatment with appropriate electrode plates. The leachate was treated with ozone for $2 \mathrm{~h}$, having the ozone pumped (flow rate of $2.5 \mathrm{~mL} \mathrm{~min}^{-1}$ ) in and distributed through the reaction vessels by diffusers placed at the bottom of the vessels. The effluent was then subjected to simultaneous electrocoagulation and ozonation processes using a stainless steel electrode set followed by an aluminium electrode set. Each electrode set contained ten quadratic, $1 \mathrm{~mm}$ thick plates in the parallel arrangement, separated by an electrical insulator. The distance between the plates was $10 \mathrm{~mm}$ (6). After the treatment with the aluminium electrode set, the suspension was subjected to slow mixing with ozone bubbles for additional $30 \mathrm{~min}$ in order to complete coagulation/ flocculation while additional $30 \mathrm{~min}$ were needed for the flock to settle. Clear water was subjected to final treatment with microwaves for $20 \mathrm{~min}$ (6).

\section{Physicochemical parameter analysis}

All methods were performed according to the Standard Methods for the Examination of Water and Wastewater (10).

Colour was determined according to 8025 APHA platinum-cobalt standard method and a 500 platinumcobalt unit's colour standard solution (Cole-Parmer, 
Chicago, USA) was used to check accuracy and performance. Turbidity was determined by 8237 absorptometric method, and 4000 NTU Formazin stock solution (Cole-Parmer, Chicago, USA) was used for the purpose of checking accuracy and performance. Suspended solids (SS) were determined by the 8006 photometric method, and chemical oxygen demand (COD) and total organic carbon (TOC) were determined by the reactor digestion method. For sample digestion, DRB 200 reactor (Hach Company, Loveland, USA) was used. Ammonia $\left(\mathrm{NH}_{4}-\mathrm{N}\right)$ was determined by 8155 salicylate method and for accuracy and performance check $10 \mathrm{mg} \mathrm{L}^{-1}$ standard solution (Hach Company, Loveland, USA) was used. All aforementioned parameters were measured using HACH DR890 colorimeter (Hach Company, Loveland, USA). Biochemical oxygen demand $\left(\mathrm{BOD}_{5}\right)$ was determined by OxiTop system (WTW, Weilheim, Germany). $\mathrm{pH}$ value, electrical conductivity (EC), and total dissolved solids (TDS) were determined by PHT027 - water quality multiparameter monitor (Kelilong Electron, Fuan Fujian, China). For calibration purpose Cole-Parmer standard solutions were used (ColeParmer, Chicago, USA).

\section{Metal analysis in water samples}

Trace metals in water samples were determined by energy dispersive X-ray fluorescence method according to Oreščanin et al. (11) with MiniPal 4 X-ray spectrometer (PANalytical, Almelo, Netherlands). Spectral data were analysed by MiniPal/MiniMate software version 3.0.-63(2.64) (PANalytical).

\section{Allium test}

Prior to the test start, the outer scales of the onion bulbs (1.5-2.0 cm diam.; A. cepa L., $2 \mathrm{n}=16)$ and the dry bottom plate were removed and the bulbs were placed in distilled water for $48 \mathrm{~h}$. Individual sets of six bulbs were used per each water sample: chemically treated leachate $(\mathrm{CT})$, electrochemically treated leachate (ETC) and untreated (original) leachate prepared in a range of serial dilutions (L $5 \%, \mathrm{~L} 25 \%$, L 50\% and L $100 \%$ ). Distilled water (pH 6.0) was used as a negative control (C). Ethyl methanesulfonate (EMS), $5 \mathrm{mmol} \mathrm{L}^{-1}$ solution (Sigma-Aldrich, St. Louis, USA) was used as a positive control mutagen. After $24 \mathrm{~h}$ of exposure, some root tips were removed from the bulbs, fixed in ethanol:glacial acetic acid $(3: 1 ; \mathrm{v} / \mathrm{v})$ and kept overnight at $4{ }^{\circ} \mathrm{C}$ before being rinsed in tap water and stained in acetocarmine (Sigma-Aldrich,
St. Louis, USA). Microscope slides were prepared by squashing the stained root tips in $45 \%(\mathrm{v} / \mathrm{v})$ glacial acetic acid to remove excess stain. One slide was prepared per bulb and all slides were examined using bright-field microscopy (Zeiss Standard 20, Carl Zeiss, Jena, Germany) at a total magnification of 1000x. Microscopical investigations were performed on three slides (replicates) with each having 1-2 root tips for each water sample. To obtain mitotic indices (MI), approximately 3000 cells (1000 cells in each of the three slides) were observed for each water sample. The number of chromosomal aberrations was recorded in approximately 300 dividing cells (preferably 100 per slide). Various types of aberrations scored were c-mitosis, laggards, chromosome breaks, anaphase bridges, and stickiness. After $72 \mathrm{~h}$ of exposure to tested water samples, the root lengths $(n=6)$ were measured and used as an index of general toxicity.

\section{Lemna test and biochemical parameters in duckweed}

L. minor L. was originally collected from the Botanical Garden, Faculty of Science, University of Zagreb. For long-term cultivation, L. minor plants were sterilised and maintained as stock cultures. The axenic cultures were grown under a 16:8 h light:dark period of cool fluorescent light $\left(90 \mu \mathrm{Em}^{-2} \mathrm{~s}^{-1}\right)$ at $24 \pm 2{ }^{\circ} \mathrm{C}$. Prior to toxicity testing, $L$. minor plants were allowed to adapt to the Steinberg medium ( $\mathrm{pH} 5.5$ ) which was modified according to Altenburger (ISO 20079 test protocol) (12) for a 2-week period (precultivation). Following the adaptation period, several healthy colonies with 2-3 fronds (from stock cultures) were transferred to Erlenmayer flasks containing modified Steinberg medium prepared with untreated (in a range of serial concentrations: 5, 25, 50 and $100 \%$ ), CT and ETC leachate samples. Duckweed plants grown on modified Steinberg medium with $\mathrm{dH}_{2} \mathrm{O}$ served as a control (C; control media). Prior to cultivation, all leachate samples were filtered using cellulose nitrate membranes (Whatman, pore size $0.45 \mu \mathrm{m})$. During pre-cultivation and cultivation, the cultures were grown under a continuous cool fluorescent light of $90 \mu \mathrm{mol} \mathrm{m}^{-2} \mathrm{~s}^{-1}$ (TLD 36W/54-765; Philips, Warszawa, Poland) at $24 \pm 2{ }^{\circ} \mathrm{C}$. Duckweed growth $(n=6)$ was determined using frond number $(\mathrm{FN})$ and dry weight (DW) as parameters $(x)$. The frond number was scored at the start of the experiments $(\mathrm{t} 0)$ and $7 \mathrm{~d}(\mathrm{t} 1)$ after. Plants were surface-dried between layers of paper towels, and the fresh weight was determined. To measure DW, plants were dried 
at $80{ }^{\circ} \mathrm{C}$ up to constant weight was obtained (usually $24 \mathrm{~h})$. Relative growth rate (RGR) was calculated from the following equation: $\mathrm{RGR}=\left(\ln x_{\mathrm{t} 1}-\ln x_{\mathrm{t} 0}\right) /$ t1-t0 (12). Dry to fresh weight ratio (DW/FW) was determined according to the calculation: dry weight (g)/fresh weight $(\mathrm{g})$.

The chlorophyll $a(\mathrm{Chl} \mathrm{a}), b(\mathrm{Chl} \mathrm{b})$ and carotenoid levels $(n=6)$ were determined in centrifuged $80 \%(v / v)$ acetone extracts and calculated using the method of Lichtenthaler (13).

The comet assay on L. minor was performed according to Gichner et al. (14) with slight modification (10 min denaturation, 20 min electrophoresis at $1 \mathrm{~V} \mathrm{~cm}^{-1}, 300 \mathrm{~mA}$ ). Three slides were evaluated per water sample. For each slide, 50 randomly chosen nuclei were analysed by fluorescence microscopy (Olympus BX51, Olympus, Melville, USA) with an excitation filter of BP 520/09 $\mathrm{nm}$ and a barrier filter of $610 \mathrm{~nm}$. A computerised image-analysis system (Komet version 5, Kinetic Imaging Ltd., Liverpool, UK) was employed. The percentage of the tail DNA (\% DNA) and median tail extent moment (TM) was used as the measure of DNA damage.

Lipid peroxidation $(n=6)$ was determined by estimating the malondialdehyde (MDA) content using the thiobarbituric acid method described by Heath and Packer (15). Antioxidant enzyme activities $(n=6)$ were analysed by first homogenising plant tissue in $50 \mathrm{mmol} \mathrm{L}^{-1} \mathrm{KPO}_{4}$ buffer (pH 7) with $1 \mathrm{mmol} \mathrm{L}^{-1}$ EDTA and polyvinylpolypyrrolidone (Sigma-Aldrich, St. Louis, USA). The homogenates were then centrifuged (3K18 centrifuge, Sigma-Aldrich, St. Louis, USA) at $25000 \mathrm{~g}$ for $30 \mathrm{~min}$ at $4{ }^{\circ} \mathrm{C}$ and supernatants were used for enzyme activity and protein content assays.

Total soluble protein contents of the enzyme extracts were estimated according to Bradford (16) using bovine serum albumin as standard.

Ascorbate peroxidase (APX; EC 1.11.1.11) activity was done following ascorbate oxidation at $290 \mathrm{~nm}$ according to Nakano and Asada (17). The activity of peroxidase (GPX; EC 1.11.1.7) was measured using guaiacol as the substrate according to Nakano and Asada (17).

Catalase (CAT; EC 1.11.1.6) activity was determined by the decomposition of $\mathrm{H}_{2} \mathrm{O}_{2}$ and according to Aebi (18). The specific activities of all enzymes were expressed as units per milligram of protein.

\section{Statistical analysis}

All the experiments were independently carried out two times, each time with three replicates $(n=6)$ for all the measurements, unless stated otherwise. Statistical analyses were performed using the STATISTICA 8.0 (StatSoft Inc., Tulsa, USA) software package. Data were compared by analysis of variance (ANOVA) to confirm the variability of data and validity of results, and Duncan's multiple range test was performed to determine the significant differences between treatments. $P<0.05$ was considered statistically significant.

\section{RESULTS AND DISCUSSION}

The leachate characteristics and efficiency of the two treatment methods in specific pollutant removal or reduction of global parameters such as colour, turbidity, and TOC is shown in Table 1. As a result of completed fermentation and waste aging processes, landfill leachate was characterised by dark grey colour, a very low $\mathrm{BOD}_{5} / \mathrm{COD}$ ratio, and a high amount of $\mathrm{Fe}$ and ammonia N. At the most general level, a low $\mathrm{BOD}_{5} / \mathrm{COD}$ ratio suggests a leachate with low concentrations of volatile fatty acids and relatively higher amounts of humic and fulvic-like compounds (1). According to the composition changes $-\mathrm{pH}>7.5$, $\mathrm{COD}<4000, \mathrm{BOD}_{5} / \mathrm{COD}<0.1$ - leachate from landfill Piškornica belongs to a stabilised type of leachate (19). Regarding the quality of the landfill leachate, the values of several physicochemical indicators (Table 1) exceeded the maximum values legally allowed in wastewater (20). Both chemical and electrochemical treatments showed high removal efficiency of all parameters - colour, turbidity, suspended solids (SS), $\mathrm{COD}, \mathrm{Fe}$, and $\mathrm{Zn}$ with the exception of TDS and ammonia in the case of chemical treatment (the final concentration of ammonia exceeded the maximum allowed value). The observed increase in TDS following chemical treatment is most likely the result of added chemicals, especially $\mathrm{CaO}$. All other components in the treated leachate were in agreement with the regulated values.

A variety of assays have been used to demonstrate the mutagenic activity of leachate toxicity and genotoxicity $(3,21,22)$. Here, toxic effects of untreated and treated old sanitary landfill leachate were evaluated by the Allium, Lemna, and comet tests. The Allium test enables the evaluation of the effects of toxic and genotoxic material through the alternations in root growth and mitotic cell division, as well as the observation of chromosomal abnormalities. The test has been frequently used for detecting environmental 
Table 1 Composition of untreated (L) and chemically (CT) or electrochemically (ECT) treated landfill leachate compared with the maximum allowed values (MAV) for wastewater suitable for discharge into natural environment.

\begin{tabular}{ccccc}
\hline Measured parameter & L & CT & ETC & MAV \\
\hline Color $\left(\mathrm{PtCo}^{2}\right)$ & 6430 & 187 & 77 & - \\
Turbidity (NTU) & 1740 & 4 & 6 & - \\
$\mathrm{SS}\left(\mathrm{mg} \mathrm{L}^{-1}\right)$ & 631 & 8 & 6 & 35 \\
$\mathrm{pH}$ & 8.11 & 7.74 & 8.44 & $6.5-9$ \\
$\mathrm{EC}\left(\mathrm{mS} \mathrm{cm}^{-1}\right)$ & 4.67 & 9.31 & 4.27 & - \\
$\mathrm{TDS}\left(\mathrm{mg} \mathrm{L}^{-1}\right)$ & 3280 & 6490 & 2980 & - \\
$\mathrm{COD}\left(\mathrm{mgL}^{-1}\right)$ & 756 & 41 & 32 & 125 \\
$\mathrm{BOD}\left(\mathrm{mg} \mathrm{L}^{-1}\right)$ & 82 & 11 & 5 & 25 \\
$\mathrm{NH}-\mathrm{N}\left(\mathrm{mg} \mathrm{L}^{-1}\right)$ & 132 & 18 & 1.4 & 10 \\
$\mathrm{TOC}\left(\mathrm{mg} \mathrm{L}^{-1}\right)$ & 312 & 12.24 & 8.70 & 30 \\
$\mathrm{Fe}\left(\mathrm{mg} \mathrm{L}^{-1}\right)$ & 2.27 & 0.031 & 0.024 & 2 \\
$\mathrm{Zn}\left(\mathrm{mg} \mathrm{L}^{-1}\right)$ & 0.71 & 0.034 & 0.031 & 2 \\
$\mathrm{Cr}\left(\mathrm{mg} \mathrm{L}^{-1}\right)$ & 0.016 & $\mathrm{ND}$ & $\mathrm{ND}$ & 0.1 \\
$\mathrm{Ni}\left(\mathrm{mg} \mathrm{L}^{-1}\right)$ & 0.027 & $\mathrm{ND}$ & $\mathrm{ND}$ & 0.5 \\
$\mathrm{Cu}\left(\mathrm{mg} \mathrm{L}^{-1}\right)$ & 0.043 & 0.008 & 0.003 & 0.5 \\
$\mathrm{~Pb}\left(\mathrm{mg} \mathrm{L}^{-1}\right)$ & 0.003 & $\mathrm{ND}$ & $\mathrm{ND}$ & 0.5
\end{tabular}

Numbers are means of two replicates. $N D=$ not determined.

mutagens as it shows a good correlation with mammalian and non-mammalian tests and the same level of sensitivity as test systems of algae and human lymphocytes (8).

Onion root-tip cell phyto- (root length), cyto(mitotic index) and genotoxicity (chromosomal abnormalities) exposed to serial dilutions of landfill leachate samples increased with higher concentration of the untreated leachate (Table 2, Figure 1). The untreated leachate caused significant reduction of $A$. cepa root length at concentrations higher than $5 \%$ and of mitotic index even under the highest leachate dilution (L $5 \%$ ) compared to the negative control (C). The negative effect of L $100 \%$ on root growth and cell division was more pronounced even in comparison with the positive control. The inhibition of mitotic index could be attributed to the effect of heavy metals on DNA and/or protein synthesis of onion root cells (3). Regarding genotoxicity, the number of aberrant cells increased with higher concentration of the untreated leachate and the most frequent abnormalities were stickiness and chromosome breaks, the latter most probably resulting from stickiness. According to Gaulden (23), stickiness causes chromosome aberrations by the physical stretching and breaking of the chromatids at the sticky sites, thus the breakage resulting from stickiness is a secondary effect that requires an anaphase movement, in contrast to the breakage resulting from direct action of mutagens on DNA. The observed chromosome aberrations might be explained by combined effects of iron with chromium and zinc (3). Regarding the relatively low levels of metals in leachate, high organic biorefractory compounds (colour, turbidity, COD) and/or ammonia could have contributed to leachate-induced genotoxicity. The results are in accordance with the study of Gajski et al. (21) in which a higher number of micronuclei, nucleoplasmic bridges and nuclear buds showed a positive correlation with biorefractory 
Table 2 Mitotic and chromosomal abnormalities of Allium cepa meristem root cells following 24 h-period exposure to untreated landfill leachate $(L)$ and chemically $(C T)$ or electrochemically (ECT) treated leachate. $d_{2} \mathrm{O}$ was used as a negative control and ethyl methanesulphonate (EMS) as a positive control

\begin{tabular}{ccccccccc}
\hline Sample & $\begin{array}{c}\text { No. } \\
\text { dividing } \\
\text { cells }\end{array}$ & C-mitosis & Laggards & $\begin{array}{c}\text { Multipolar } \\
\text { spindle }\end{array}$ & Breaks & $\begin{array}{c}\text { Anaphase } \\
\text { bridges }\end{array}$ & $\begin{array}{c}\text { Sticky } \\
\text { chromosomes }\end{array}$ & $\begin{array}{c}\text { Abberant } \\
\text { cells (\%) }\end{array}$ \\
\hline C & 301 & 1 & 1 & 0 & 0 & 2 & 2 & 2.0 \\
EMS & 144 & $15^{*}$ & $8^{*}$ & 3 & $12^{* *}$ & $5 *$ & $18^{* *}$ & 42.4 \\
CT & 233 & 5 & 0 & 1 & 1 & 1 & 4 & 5.2 \\
ECT & 289 & 2 & 1 & 0 & 0 & 2 & 3 & 2.8 \\
L 5 \% & 273 & 3 & $6 *$ & 1 & 0 & 1 & $8^{*}$ & 7.0 \\
L 25 \% & 219 & 4 & 0 & 2 & 4 & 1 & $24^{* *}$ & 16.0 \\
L 50 \% & 158 & 1 & 3 & 0 & 6 & 0 & $27^{* *}$ & 23.4 \\
L 100 \% & 69 & 2 & 1 & 0 & $9 *$ & 0 & $10^{*}$ & 31.9 \\
\hline$* \mathrm{P}<0.05, * * \mathrm{P}<0.001$ & & & & & & &
\end{tabular}

compounds and ammonia present in the sanitary landfill leachate.

On the other hand, both applied treatment methods were efficient in reducing (chemical treatment) or completely removing (electrochemical treatment) toxic and genotoxic effects of landfill leachate (Table 2, Figure 1). With respect to the negative control, chemical treatment showed phyto- and cytotoxic effects $(12 \%$ and $22 \%$ decrease in root length and MI, respectively) though with respect to the undiluted leachate, toxicity was markedly reduced $(60 \%$ and $80 \%$ increase in root length and MI, respectively). The number of chromosomal abnormalities was also higher in A.cepa roots exposed to the chemically treated leachate when compared to the negative control, but it was lower in comparison to the highest dilution of landfill leachate (L $5 \%$ ). Also, none of the individually observed aberrations showed statistical significance compared to positive or negative controls (Table 1). The observed toxic effect of the chemically treated leachate could be related to ammonia phytotoxicity (24) though chemicals used in the treatment process ( $\mathrm{CaO}$ and clinoptilolite) and/or their interaction with other substances present in the landfill leachate could also be the reason for such effects.

Several studies have confirmed that duckweed ( $L$. minor) is suitable as a test organism in industrial and surface water monitoring due to its sensitivity to a wide range of aquatic pollutants and capability to accumulate certain chemicals $(25,26)$. Leachate concentrations higher than $25 \%$ caused necrosis of plant tissue in less than $24 \mathrm{~h}$. Phytotoxicity of the leachate from the sanitary landfill Piškornica was evident as its influence on duckweed growth rate was remarkable - a $62 \%$ and $70 \%$ decline of growth rate based on the frond number and dry weight, respectively, was observed following seven-day exposure to $25 \%$ concentration of the original leachate (Figure 2a). Even L $5 \%$ markedly reduced the growth rate based on the frond number. Due to complexity of the leachate and interactions among numerous constituents in the landfill leachate, it was difficult to identify the contaminants responsible for toxicity, but the growth reduction observed in our study could be the result of suppression of cell elongation rate exerted by $\mathrm{Fe}, \mathrm{Zn}$, and $\mathrm{Ni}$ and possibly by ammonia $(24,27)$. Severe growth inhibition of L.minor was noticed at ammonia concentrations above $8.85 \mathrm{mg} \mathrm{L}^{-1}$ after seven-day exposure (7). Dry to fresh weight ratio (DW/FW) measured at the end of the seven-day experiment has shown inverse relation in comparison with RGR (Figure $2 \mathrm{~b}$ ) - 22 and $46 \%$ increase in DW/FW was recorded under L $5 \%$ and L $25 \%$, respectively, compared to control. This could be explained by the aforementioned ability of duckweed, along with all other species within the Lemnaceae family, to 
accumulate various pollutants including heavy metals. It has been shown that accumulation of heavy metals disturbs the plant water status, which eventually results in osmotic stress and growth reduction (28).

Pigment content has shown to be a very consistent biomarker in relation to growth rates. At the end of the seven-day exposure, duckweed cultivated on L $25 \%$ showed signs of necrosis (dark brown necrotic spots). Accordingly, a marked decrease in Chl a, b, and carotenoids in comparison with control was detected in plants exposed to L $25 \%$ while L $5 \%$ did not induce such significant effects (Figure 2c, d). The inhibition of photosynthetic pigments may be the consequence of a negative action of $\mathrm{Ni}, \mathrm{Fe}$, and $\mathrm{Zn}$ on the electron transport chain, $\mathrm{Mg}$ ions availability, inhibition of enzymes associated with chlorophyll biosynthesis or peroxidation processes in chloroplast membrane lipids by the reactive oxygen species (29). Also, ammonia toxicity could be the reason for photosynthetic pigments decrease as the ammoniainduced growth suppression was positively correlated with enhanced damage to the photosynthetic centres (24).

Similar to the results obtained by the Allium test, both treatments significantly reduced leachate-induced phytotoxicity, but electrochemical treatment was again proved to be more efficient as no significant effect either on growth or photosynthetic pigments was recorded following plant exposure to the ETC sample (Figure 2a-c). In contrast, the CT sample caused significant decrease of growth rate (between 28 and $38 \%$ depending on the growth parameter) and Chl a and $70 \%$ increase in DW/FW compared to control and L $5 \%$ (Figure 2a-c). However, with respect to $25 \% \mathrm{~L}$, toxicity was markedly reduced (averagely 50 and $35 \%$ increase in growth rate and photosynthetic pigments, respectively). The notable effect of the chemically treated leachate on growth is probably the result of residual ammonia and accumulation of chemicals used in the treatment process as indicated by high TDS and increased DW/FW.

A significant rise in MDA, compared to control, was recorded in duckweed exposed to $\mathrm{L} 25 \%$

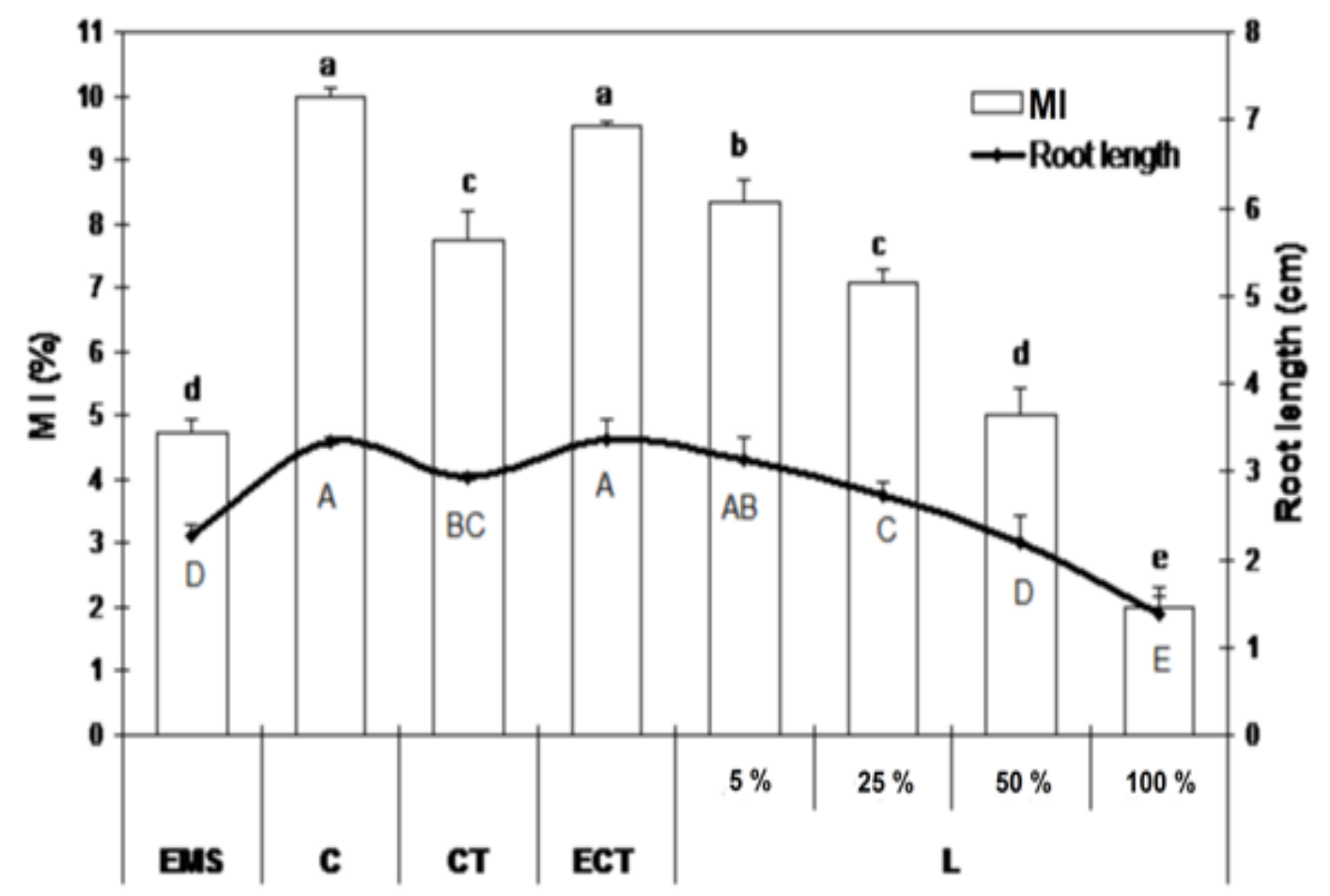

Figure 1 Root length (cm) and mitotic index (\%) of Allium cepa root-tip cells following 24 h-period exposure to serial dilutions of untreated leachate ( $L 5,25,50$, and $100 \%$ ) and chemically $(C T)$ or electrochemically $(E C T)$ treated leachate. d $\mathrm{H}_{2} \mathrm{O}$ was used as a negative control and $5 \mathrm{mmol} L^{-1} E M S$ was employed as a positive. Standard deviations were presented by error bars. Different letters indicate significantly different values at $\mathrm{P}<0.05$. 
suggesting that certain substances from leachate caused damage to membrane lipids (Figure 2e). Oxidative injury to $L$. minor biomembrane can be attributed to $\mathrm{Zn}, \mathrm{Ni}$, and $\mathrm{Cr}$ but also to $\mathrm{Fe}$ since it was present in larger quantities in landfill leachate samples. Oppositely to $\mathrm{Fe}$, a redox active metal, non-redox metals such as $\mathrm{Zn}, \mathrm{Ni}$, and $\mathrm{Cr}$ increase the production of reactive oxygen species (ROS) indirectly by interfering with the plant's antioxidant defence system (27). Zhu et al. (30) observed enhanced ROS generation via Mehler reaction and consequent increased lipid peroxidation as a result of ammonia. Antioxidative enzymes, such as peroxidase and catalase, can serve as important markers of stress caused by environmental pollution (31). The activity of peroxidases and catalase showed a significant increase in response to L $25 \%$ (Figure $2 \mathrm{~g}, \mathrm{~h}$ ). The results suggest induction of oxidative stress after exposure to leachate but also demonstrate duckweed's capacity to upregulate its antioxidative defence. In several studies, heavy metals have been found to be potent inducers of catalase and peroxidase $(27,29$, 31). Regarding the effects of the treated leachate, significant changes in MDA and activities of GPX and catalase were once again detected only following duckweed exposure to the chemically treated leachate (Figure 2e, g, h). A simplified comet procedure modified for plant tissue allows rapid yet sensitive

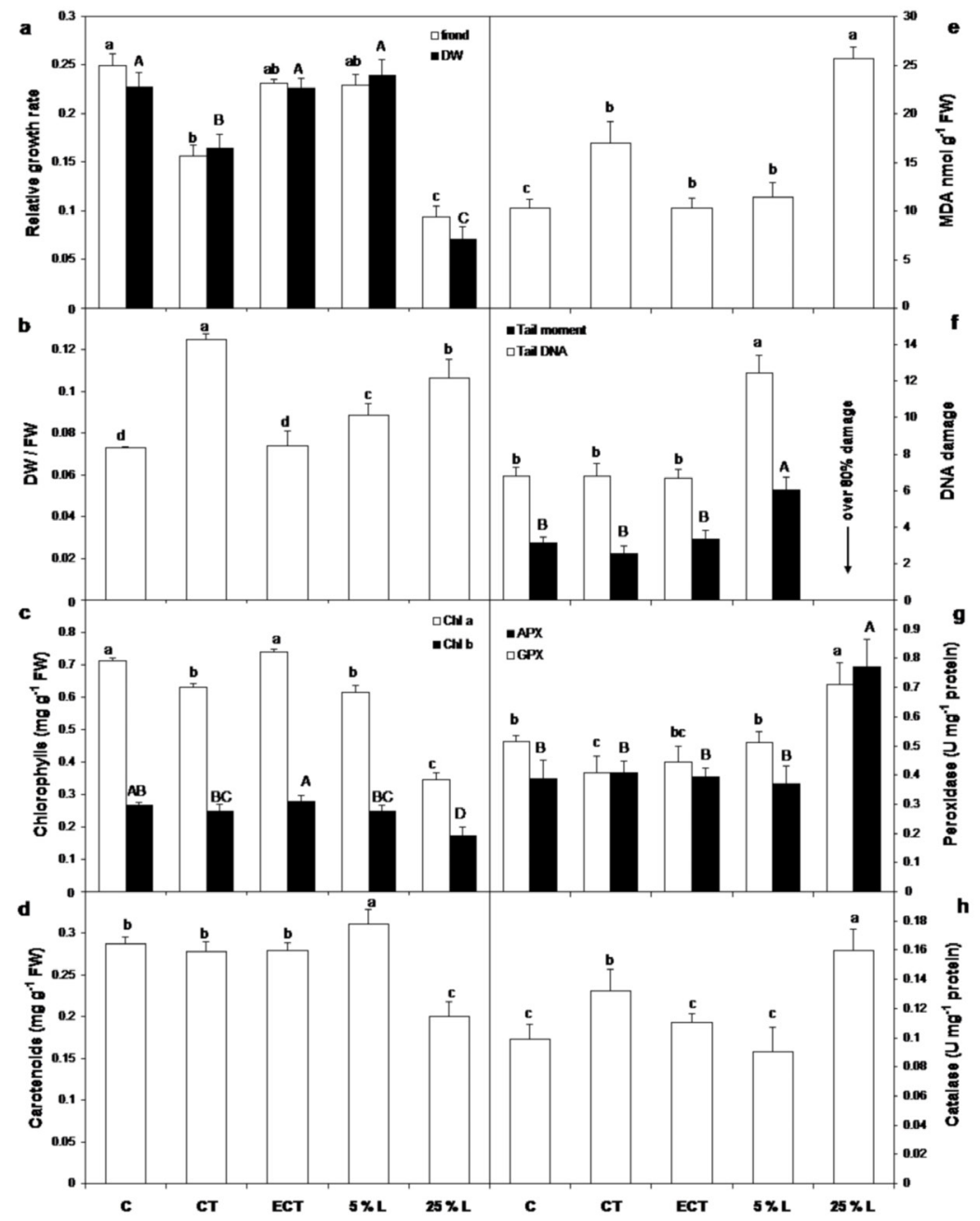

Figure 2 (a) Relative growth rate based on frond and DW as parameters, (b) dry to fresh weight ratio (DW/FW), (c) contents of chlorophyll a (Chl a), chlorophyll b (Chl b) and (d) carotenoids, (e) malondialdehyde content (MDA), (f) DNA damage - tail moment and tail DNA, (g) ascorbate (APX) and guaiacol (GPX) peroxidase activity and (h) catalase activity in duckweed grown for $7 d$ in control media $(C)$, media containing untreated leachate ( 5 and $25 \%$ ) and chemically (CT) or electrochemically (ECT) treated leachate. Standard deviations were presented by error bars. Different letters indicate significantly different values at $\mathrm{P}<0.05$. 
determination of DNA damage. The results obtained by comet assay parameters (tail moment and tail DNA) showed significant DNA damage even at L 5 \% (Figure $2 \mathrm{f}$ ) while almost total DNA damage to $L$. minor nuclei was observed at L $25 \%$ (DNA damage over $80 \%$ ). Both parameters of DNA damage in duckweed exposed to CT and ECT showed values similar to those in the control. In the study of Widziewicz et al. (32), old solid waste landfill leachate also showed genotoxic effects as determined by the comet assay using human and Daphnia magna cells. However, in contrast to our study, the application of the classical biological treatment did not completely remove genotoxic character of the treated leachate.

\section{CONCLUSIONS}

The applied treatment methods were both highly efficient in removing leachate genotoxicity. Electrochemical treatment was equally efficient in removing leachate toxicity unlike chemical treatment, as residual toxicity of leachate was noted after its application. Strong toxicity and genotoxicity of the untreated landfill leachate observed in the study can only partly be attributed to ammonia and relatively low heavy metal levels and is probably the result of some unidentified pollutants not covered by the performed chemical analysis.

\section{Acknowledgements}

This study has been funded by the Croatian Ministry of Science, Education and Sport, as part of Projects no. 119-1191196-1202. The authors declare that they have no conflict of interest.

\section{REFERENCES}

1. Kjeldsen P, Barlaz MA, Rooker AP, Baun A, Ledin A, Christensen TH. Present and long-term composition of MSW landfill Leachate: a review. Crit Rev Environ Sci Technol 2002;32:297-336. doi: 10.1080/10643380290813462

2. Bortolotto T, Bertoldo JB, da Silveira FZ, Manganelli Defaveri T, Silvano J, Pich CT. Evaluation of the toxic and genotoxic potential of landfill leachates using bioassays. Environ Toxicol Pharmacol 2009;28:288-93. doi: 10.1016/j. etap.2009.05.007

3. Chandra S, Chauhan LK, Murthy RC, Saxena PN, Pande PN, Gupta SK. Comparative biomonitoring of leachates from hazardous solid waste of two industries using the Allium test.
Sci Total Environ 2005;347:46-52. doi: 10.1016/j. scitotenv.2005.01.002

4. Sang N, Li G, Xin X. Municipal landfill leachate induces cytogenetic damage in root tips of Hordeum vulgare. Ecotoxicol Environ Saf 2006;63:469-73. doi: 10.1016/j. ecoenv.2005.02.009

5. Oreščanin V, Ruk D, Kollar R, Lovrenčić Mikelić I, Nad K, Mikulić N. A combined treatment of landfill leachate using calcium oxide, ferric chloride and clinoptilolite. J Environ Sci Health A Tox Hazard Subst Environ Eng 2011;46:323-8. doi: 10.1080/10934529.2011.539118

6. Oreščanin V, Kollar R, Ruk D, Nad K. Characterization and electrochemical treatment of landfill leachate. J Environ Sci Health A Tox Hazard Subst Environ Eng 2012;47:462-9. doi: 10.1080/10934529.2012.646146

7. Wang W. Ammonia toxicity to macrophytes (common duckweed and rice) using static and renewal methods. Environ Toxicol Chem 1991;10:1173-7. doi: 10.1002/ etc. 5620100909

8. Leme DM, Marin-Morales MA. Allium cepa test in environmental monitoring: A review on its application. Mutat Res 2009;682:71-81. doi: 10.1016/j.mrrev.2009.06.002

9. Fiskesjö G. The Allium test as a standard in environmental monitoring. Hereditas 1985;102:99-112. PMID:3988545

10. American Public Health Association (APHA), American Water Works Association (AWWA), Water Environment Federation (WEF). Standard Methods for Examination of Water and Wastewater. 22 ${ }^{\text {nd }}$ ed. Washington: American Public Health Association; 2012.

11. Oreščanin V, Lovrenčić I, Mikelić L, Lulić S. Applicability of MiniPal 4 compact EDXRF spectrometer for soil and sediment analysis. X-ray Spectrom 2008;37:508-11. doi: 10.1002/xrs. 1079

12. ISO/DIS 20079, 2004. International Organization for Standardization / Draft International Standard. Water quality - Determination of the toxic effect of water constituents and wastewater on duckweed (Lemna minor) - Duckweed growth inhibition test.

13. Lichtenthaler HK. Chlorophylls and carotenoids: pigments of photosynthetic membranes. Methods Enzymol 1987;148:350-82. doi: 10.1016/0076-6879(87)48036-1

14. Gichner T, Patková Z, Száková J, Demnerová K. Cadmium induces DNA damage in tobacco roots, but no DNA damage, somatic mutations or homologous recombination in tobacco leaves. Mutat Res 2004;559:49-57. doi: 10.1016/j. mrgentox.2003.12.008

15. Heath RL, Packer L. Photoperoxidation in isolated chloroplasts. I. kinetics and stoichiometry of fatty acid peroxidation. Arch Biochem Biophys 1968;125:189-98. doi: 10.1016/0003-9861(68)90654-1

16. Bradford MM. A rapid and sensitive method for the quantitation of microgram quantities of protein utilizing the principle of protein-dye binding. Anal Biochem 1976;72:24854. doi: 10.1016/0003-2697(76)90527-3

17. Nakano Y, Asada K. Hydrogen peroxide is scavenged by ascorbate-specific peroxidase in spinach chloroplasts. Plant Cell Physiol 1981;22:867-80.

18. Aebi H. Catalase in vitro. Methods Enzymol 1984;105:1216. PMID: 6727660

19. Foo KY, Hameed BH. An overview of landfill leachate treatment via activated carbon adsorption process. J Hazard Mater 2009;171:54-60. doi: 10.1016/j.jhazmat.2009.06.038 
20. Pravilnik o graničnim vrijednostima opasnih i drugih tvari u otpadnim vodama [Ordinance on limit values of indicators of hazardous and other substances in wastewater, in Croatian]. Narodne novine 94/2008.

21. Gajski G, Oreščanin V, Garaj-Vrhovac V. Chemical composition and genotoxicity assessment of sanitary landfill leachate from Rovinj, Croatia. Ecotoxicol Environ Saf 2012;78:253-9. doi: 10.1016/j.ecoenv.2011.11.032

22. Kwasniewska J, Nałęcz-Jawecki G, Skrzypczak A, Płaza GA, Matejczyk M. An assessment of the genotoxic effects of landfill leachates using bacterial and plant tests. Ecotoxicol Environ Saf 2012;75:55-62. doi: 10.1016/j. ecoenv.2011.08.020

23. Gaulden ME. Hypothesis: some mutagens directly alter specific chromosomal proteins (DNA topoisomerase II and peripheral proteins) to produce chromosome stickiness, which causes chromosome aberrations. Mutagenesis 1987;2:357-65. doi: 10.1093/mutage/2.5.357

24. Britto DT, Kronzucker HJ. $\mathrm{NH}_{4}^{+}$toxicity in higher plants: a critical review. J Plant Physiol 2002;159:567-84. doi: 10.1078/0176-1617-0774

25. Radić S, Stipaničev D, Cvjetko P, Lovrenčić Mikelić I, Marijanović Rajčić M, Širac S, Pevalek-Kozlina B, Pavlica M. Ecotoxicological assessment of industrial effluent using duckweed (Lemna minor L.) as a test organism. Ecotoxicology 2010;19:216-2. doi: 10.1007/s10646-009-0408-0

26. Radić S, Stipaničev D, Cvjetko P, Marijanović Rajčić M, Šrac S, Pevalek-Kozlina B, Pavlica M. Duckweed Lemna minor as a tool for testing toxicity and genotoxicity of surface waters. Ecotoxicol Environ Saf 2011;74:182-7. doi: 10.1016/j.ecoenv.2010.06.011

27. Horvat T, Vidaković-Cifrek Ž, Oreščanin V, Tkalec M, Pevalek-Kozlina B. Toxicity assessment of heavy metal mixtures by Lemna minor L. Sci Total Environ 2007;384:22938. doi: 10.1016/j.scitotenv.2007.06.007

28. Perfus-Barbeoch L, Leonhardt N, Vavasseur A, Forestier C. Heavy metal toxicity: cadmium permeates through calcium channels and disturbs the plant water status. Plant J 2002;32:539-48. doi: 10.1046/j.1365-313X.2002.01442.x

29. Hou W, Chen X, Song G, Wang Q, Chang CC. Effects of copper and cadmium on heavy metal polluted waterbody restoration by duckweed (Lemna minor). Plant Physiol Biochem 2007;45:62-9. PMID: 17300947

30. Zhu Z, Gerendas J, Bendixen R, Schinner K, Tabrizi H, Sattelmacher B, Hansen U-P. Different tolerance to light stress in $\mathrm{NO}_{3}^{-}$- and $\mathrm{NH}_{4}^{+}$- grown Phaseolus vulgaris L. Plant Biol 2000;2:558-70. doi: 10.1055/s-2000-7498

31. Fatima RA, Ahmad M. Certain antioxidant enzymes of Allium cepa as biomarkers for the detection of toxic heavy metals in wastewater. Sci Total Environ 2005;346:256-73. PMID: 15993699

32. Widziewicz K, Kalka J, Skonieczna M, Madej P. The comet assay for the evaluation of genotoxic potential of landfill leachate. Sci World J 2012;2012:435239. doi: $10.1100 / 2012 / 435239$ 


\section{Sažetak}

Uklanjanje toksičnosti i genotoksičnosti procjedne vode s odlagališta uporabom dviju metoda pročišćavanja

Procjedne vode s aktivnih i zatvorenih odlagališta krupnog otpada mogu biti glavni izvor onečišćenja podzemnih i površinskih voda. U ovom su radu putem Lemna-, Allium- i komet-testa procijenjeni toksični i genotoksični učinci procjedne vode prikupljene sa starog odlagališta otpada Piškornica (Koprivnica) prije i nakon kemijskog ili elektrokemijskog pročišćavanja. Dodatni pokazatelji toksičnosti praćeni u vodenoj leći bili su sadržaj fotosintetskih pigmenata i malondialdehida (indikator lipidne peroksidacije) te aktivnosti antioksidacijskih enzima. U toj je biljci $25 \%$-tno razrjeđenje procjedne vode uzrokovalo smanjenje rasta i sadržaja pigmenata dok je lipidna peroksidacija porasla unatoč stimulaciji antioksidacijskih obrambenih mehanizama. Komet testom je utvrđeno oštećenje molekule DNA u stanicama vodene leće. Glede Alium testa, nepročišćena procjedna voda uzrokovala je inhibiciju diobe u luku (Allium cepa) te pojavu mitotskih i kromosomskih aberacija. Iako su obje metode pročišćavanja bile vrlo učinkovite u uklanjanju genotoksičnih tvari prisutnih u odlagališnom eluatu, elektrokemijska metoda pokazala se učinkovitija u uklanjanju toksičnih tvari iz eluata, te time i pogodnija za obradu takvih vrsta eluata prije njihova ispuštanja u okoliš. Kako su odlagališni eluati zbog svoje genotoksičnosti opasni za ljudsko zdravlje i okoliš općenito, rezultati ovog istraživanja pokazuju da bi se testovi toksičnosti i genotoksičnosti trebali upotrebljavati u procjeni rizika odlagališnih eluata, zajedno s fizikalno-kemijskom analizom.

KLJUČNE RIJEČI: Allium-test; Lemna-test; indikatori oksidacijskog stresa; komet-test; pročišćavanje vode

\section{CORRESPONDING AUTHOR:}

Sandra Radić Brkanac

Department of Biology, Faculty of Science, University of Zagreb

Rooseveltov trg 6

HR-10000, Zagreb, Croatia

E-mail: sandra@biol.pmf.hr 